\title{
Proposed Model of Business Retail Continuity Process during Pandemic Covid-19 Based on Risk identification and Response
}

\author{
Irsa Indriati PRATIWI ${ }^{1}$ \\ Atik APRIANINGSIH ${ }^{2}$ \\ Muhammad Zhafir AFIF ${ }^{3}$ \\ Anindia Pratiwi PUTRI 4
}

DOI: $10.24818 / \mathrm{mer} / 2021.12-07$

\begin{abstract}
Recognizing competitive strategies, the retail industry must anticipate business risks. Business risk is related to managerial risk, and it depends on its ability to adapt its policies to unforeseen events and changes. Currently, the whole world is facing the Covid-19 outbreak. In facing the challenges and risks from Covid-19, retail businesses must manage and respond to these risks so that their business can recover and business continuity is realized. This study seeks to identify the risks experienced by retail businesses in Indonesia during the COVID-19 pandemic and what risk management strategies are appropriate for business continuity and retail business recovery. Previous studies have explained the impact of Covid-19 on the retail industry. However, there is still a lack of research that tries to identify the risks and how to overcome them. This research will try to fill that gap. Semi-systematic or narrative review techniques were conducted in this study. The study's result is a framework related to risk management in retail industries. This study contributes to knowledge and practical implication regarding the risk that the retail industry is experiencing during the COVID-19 pandemic.
\end{abstract}

KEYWORDS: business continuity process, business retail, pandemic Covid-19, risk identification, risk response.

\section{JEL CLASSIFICATION: $M 00$}

\section{INTRODUCTION}

The retail industry sells items directly to clients who want to utilize the product from a single point (commercial, market, department store, etc.). In Indonesia, retail stores have associations with modern stores. According to the President of Indonesia's Regulation (Peraturan, 2012), modern shop a retail business is a modern store with a self-service system that sells various types of retail items in a minimarket, supermarket, department store, hypermarket, or wholesaler that has grown into a cult following. Retail companies seek a competitive edge by organizing adaptation, transformation, and internal organizational restructuring (Moretta Tartaglione et al., 2019). Realizing a competitive strategy, the retail industry must also do these things to anticipate the business risks. Business risk is related to managerial risk, and it depends on the companies' capacity to adapt its policies to unforeseen events and changes (Chaffai \& Dietsch, 2015).

\footnotetext{
${ }^{1}$ Institut Teknologi Bandung, Indonesia, irsa_indriati@sbm-itb.ac.id (corresponding author)

2 Institut Teknologi Bandung, Indonesia, atik.apri@sbm-itb.ac.id

${ }^{3}$ Institut Teknologi Bandung, Indonesia, zhafir.afif@sbm-itb.ac.id

${ }^{4}$ Institut Teknologi Bandung, Indonesia, anindia_pratiwi@sbm-itb.ac.id
} 
From day to day, many unexpected disasters occur in every part of the world, such as natural disasters and disease outbreaks. Currently, the whole world is facing the Covid-19 outbreak. To stop the coronavirus from spreading, numerous countries carry out emergency orders or quarantines. In Indonesia, retail sales declined throughout 2020 as Large-Scale Social Restrictions (PSBB) and declining consumer power hurt key retail channels (International, 2021). In 2021 the situation is better because customers begin to receive the vaccine, and the virus threat decreases, which will allow retail channels to recover from 2021. However, the recovery is generally likely to be progressive (International, 2021).

The Previous study conducted by Fabeil et al., (2020) found that entrepreneurs based in Sabah, Malaysia, demonstrated their ability to stay in business during Covid-19 by taking multiple business continuity approaches and recovery strategies. Then another previous study on Business Continuity Management on organizational performance (Bakar et al., 2015) mentioned two indicators of non-financial performance and financial effect in the business continuity. Business continuity helps organizations produce goods and services and convert them into value to secure continuity of organizational resources and processes to focus on recovery or ensuring continuity of operations (Niemimaa et al., 2019).

Based on the data from Economics (2020) regarding Year of Year (YoY) revenue of the Indonesian retail industry, the authors identified that the problem being experienced by the retail industry in Indonesia is income fluctuations throughout the COVID-19 pandemic from April 2020 to the end of April 2021. This phenomenon explains that the retail business is trying to solve the problems to maintain to survive (business continuity). To realize business continuity, retail businesses must manage risks that can affect their performance during the pandemic by conducting emergency response and crisis management. These two things are needed to be able to realize business recovery. Business continuity will not be realized without business recovery because this is the last stage in the business continuity process. So in facing the challenges and risks from Covid-19, retail businesses must be able to manage and respond to these risks so that their business can recover and business continuity is realized.

This study seeks to identify any risks that arise during the pandemic in the retail business from the explanation above. As well as identifying what responses must be taken to overcome these risks to help businesses recover and realize business continuity during a pandemic. The previous research mentioned above explains that it is important for the retail industry to anticipate the risks. It is also explained that at this time, COVID-19 was the toughest risk experienced by the retail industry. Previous research has identified the retail industry impact of Covid-19. However there is still a lack of research that tries to identify the risks and how to overcome them. This research will try to fill that gap. In comparison to prior research, this study aims to determine the risks faced by retail firms in Indonesia throughout the COVID-19 pandemic and the suitable risk management measures for business continuity and recovery. This research is expected to result in the development of a risk model and appropriate response strategies for resolving problems created by the Covid-19 epidemic in the retail industry.

The next part of this study will explain the literature study in retail business process continuity, the methodology of taking research to support conceptual models, then the results and discussion of the research, and finally conclusions obtained from this study. 


\section{LITERATURE REVIEW AND THEORETICAL FRAMEWORK 2.1 Retail business}

Retail, one of the most extensive and diverse industries globally and surviving, is undergoing a widespread transformation that is transforming a formerly basic means of doing company into a highly automated and complex type of management. (Mulhern, 1997). According to Mulhern (1997), the retail concept refers to actions related to the sale to end-users of goods and services (individuals and households). Then, Kotler (1994) explicitly defines retail only concerning products purchased for personal use. Non-business restrictions are implied in the terms "final" and "final". Retailing is typically done in retail stores or services, but it can also be done directly through sales machines, door-to-door sales, or digital channels (William M. et al., 2014). The retail practice encompasses a greater number of activities, as retailers expand their target market boundaries and develop new ways to interact with clients and channel partners.

\subsection{Business continuity process of retail business}

Business continuity (BC) has its roots in disaster recovery plans research in the 1970s (Niemimaa et al., 2019). Because the organization is susceptible in practice to different disruptive events that can endanger business continuity (Zeng \& Zio, 2017). BC is defined as an organization's ability to maintain acceptable levels of product or service delivery in the aftermath of disruptive events (Zeng \& Zio, 2017), and is a means of anticipating and overcoming disruptions by organizations and thus reducing the risk of loss. It's possible that business activities will be able to continue (Fani \& Subriadi, 2019).

$\mathrm{BC}$ is defined as the integration of technical and social systems that enable effective organizational defense (Supriadi \& Sui Pheng, 2018). Other than that, BC represents a shift from a scenario and event-based approach in the risk management perspective to critical value-added activities, for example, the ability of an institution to transport, produce or communicate (Taarup-Esbensen, 2021). According to (Karmarkar \& Mangal, 2007), their study found that retail organizations realized the need for BC. Retailers provide and sell products/commodities to final consumers for consumption, not for resale. Retail displays certain characteristic features that appear to reduce incentives for sustainability planning (Karmarkar \& Mangal, 2007). Therefore, a business continuity process model for the retail industry is needed by identifying risk management for continuity and recovery responses that can be used repeatedly and updated regularly.

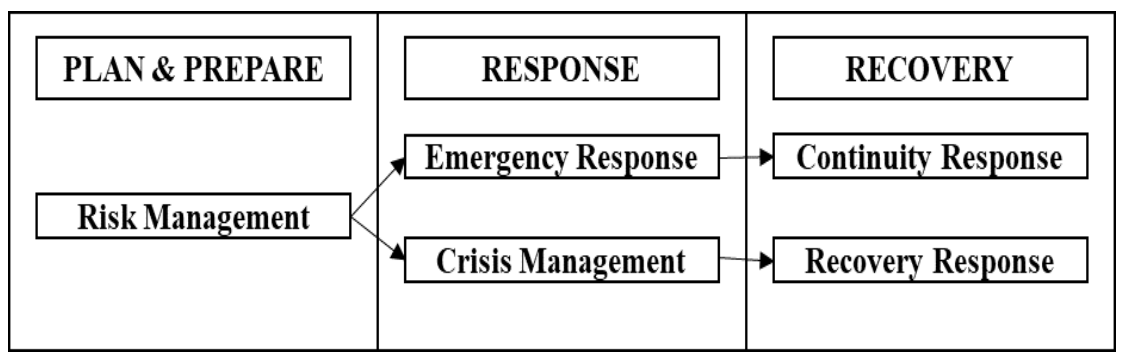

Figure 1. Business Continuity Management Process

Source: adapted from Griffith University (2021) 


\subsection{Risk management}

Internal and external events that increase or decrease the organization's expenditures or revenues are referred to as risks, and many people can do repetition negatively to impact financial performance (Sheehan, 2010). Risk management is described as a systematic and comprehensive approach aimed at identifying, organizing, and responding to risk variables to accomplish project objectives (Bahamid \& Doh, 2017). Risk management helps in estimating future risks and provides strategies and tools for comprehensive measures such as resilience, business continuity planning, and so on (Purpura, 2013). The objective is to maximize the quality, time, and cost of the project by stabilizing the input necessary to control the risks with the advantages (Buganová \& Šimíčková, 2019). Risk management is also linked to the treatment of hazards, which can be seen as a cycle of individual phases to reduce losses and damage resulting from crises (Zagorecki et al., 2013).

The initial stage of risk management is risk identification. The significance of risk identification is defined by the business's requirement to know the risks it faces (Tchankova, 2002). Effective risk management requires accurate risk identification. If risk managers cannot identify all potential losses or profits that might affect the business, these unidentified risks will become unmanageable (Scroggins et al., 1990). The second phase of risk management is risk estimation. The risk assessment phase is intended to assess frequency (or likelihood) and the potential effects on the specific risk (Pantano et al., 2013). However, the study from Pantano et al. (2013) is confined to the first two phases: risk identification and risk estimation, whereas the third phase, risk evaluation, can be the subject of more extensive investigations, which is the gap that this study will address.

Based on that, we identified seven general potential risks that general business faces, specifically. We will explain more about the risk for department store business in the discussion part.

\subsubsection{Strategic risk}

According to (Slywotzky \& Drzik, 2005), strategic risks are a number of foreign events and trends that can ruin the growth and value of a company. One of the most distinguishing features of strategic risk is that it is frequently triggered by low-frequency, high-impact hazards (Allan \& Beer, 2006). The Slywotzky \& Drzik (2005) seventeenth classification of strategic risk is industry, technology, brand, competitors, customers, projects, and stagnating companies, with solutions suggested for each. Essentially, strategic risk refers to events or decisions that might prevent an organization from achieving its goals. It also refers to the risk of a company's strategic decisions being erroneous or failing to adjust effectively to changing circumstances.

\subsubsection{Compliance risk}

The potential for the exposure of an organization to legal fines, financial liquidation, and loss from non-compliance with industry norms and regulations, internal guidelines, or recommended best implementation is known as the risk of compliance. Tax administrations prioritize tax compliance, especially in emerging countries with limited resources but largescale development goals (Bornman \& Ramutumbu, 2019). Compliance risk management, according to the OECD (2004), is a systematic method of identifying, analyzing, rating, and processing tax compliance concerns (e.g., failure to report tax liabilities properly, failure to 
register, etc.). It comprises well-defined actions, like risk management in general, is aimed at encouraging improved decision-making. European Commission (2010) the compliance risk management framework shall be applied in a context that may be considered to be playground and game rules. The goals express the objective of the match, what to reach, and how to play the match to achieve the goals (European Commission, 2010).

\subsubsection{Operational risk}

The phrase "operational risk" is described as "the risk of loss due to inadequate or failing internal processes, people, and systems, or external events". Operational risk is the risk that a corporation confronts due to what its personnel may or may not do, either intentionally or accidentally. In other words, it refers to the risks posed by internal procedures, people, and systems failing. It is distinct from both financial and systematic risk, and it varies by industry. Operational risk is the collection of dangers that a company faces while operating in a specific industry. It's a form of company risk that stems from internal issues rather than external ones. There are ten categories of operational risk (Meyer \& Quell, 2016): IT disruption, data compromise, risk resilience, theft and fraud, the risk from third parties, risks from behavior, regulation, change, geopolitical risk, and well-being of employees.

\subsubsection{Financial risk}

Financial risk definitions are typically classified into two categories. The first approach, which is related to financial risk, views risk as a hazard of prospective losses. It is expressed in terms of investment risk (assets) and the feasibility of constructing a liability structure (Chapman, 2006). The second approach views financial risk as to the likelihood of experiencing adverse financial outcomes due to various circumstances. This suggests that financial risk is a sophisticated risk, as it encompasses all enterprise risks and is quantifiable (Hawkins, 2006). Financial risk is generally divided into systematic risk and unsystematic risk. Unsystematic risk is the improbability associated with a business or industry venture. Unsystematic risks occur in the form of strikes, individual risks (non-diversified investment), or a new competitor who can remove the significant market share from the company invested or a controlled change in sales by reducing sales, changing management, recalling products, or a labor strike (Dowen, 1988). Smaga (2014) defines systemic risk as to the potential for a shock to lead to major (e.g. macro-finance) imbalances, impeding the functioning of the financial system and seriously affecting the real economy (e.g., economic growth).

\subsubsection{Reputational risk}

As the reputation of a company is its most valuable asset, controlling it is one of the main tasks of management and board member. Depending on how decisions are made, future uncertainties maybe both threats and opportunities. Stakeholders are engaged in an informal consultation process to build confidence in the future of the organization and to understand the contribution of the organization to the sustainability of society and strengthen its "social license to operate" (Klewes \& Wreschniok, 2009). Outside of the organization, reputation is shaped. A reputational risk issue typically involves the media and public statements made by consumers, employees, and other stakeholders. The techniques and analyses used to quantify and monitor reputation risk are distinct from those used in traditional risk management, focusing inward on events occurring within a company or under its control. Since reputation risk is compounded, the incident that produces it frequently also constitutes another (business) risk with its own set of facts and implications for the organization (Heil, 2018). According to (Šontaitè-Petkevičienè, 2014), three factors influence a company's exposure to reputational 
risk. The first is to determine whether its reputation outweighs its true character. The second factor is the degree to which external beliefs and expectations change, which can either widen or (less likely) close this gap. The third factor is the effectiveness of internal coordination, which can also influence the gap.

\subsection{Emergency management}

Pandemic Covid-19 can be categorized as a disaster and uncertainty condition. Emergency management is one of the risk responses in that category. Emergency Management is the management function to establish a framework whereby communities can reduce risk exposure and respond to disasters (McEntire, 2007). (Bullock et al., 2006) describe emergency management as "the science of risk assessment and risk mitigation." In this context, we define emergency management as the planning and coordination of response to anticipated crises and disasters and the coordination of response and resources in these events. Emergency Management is the process of coordination and management of the prevention, preparedness, response, and recovery of resources and duties emergency management. Collective and cooperative emergency teamwork from various emergency agencies is needed to realize effective emergency management requirements. Preparedness in emergency response is an important element of the emergency management system for emergency response operations (Subramaniam et al., 2010). In previous research by Coleman (2005) the management of emergencies consists of three phases, namely emergency relief planning, response, and recovery. There are four phases in emergency management to respond to the risk (Petak, 1985):

- Mitigation-Decide what to do if danger is identified for society's health, security, or social welfare.

- Preparedness-Develop a response and training plan for life protection first responders and reduce damage to catastrophes, including identifying essential resources and concluding necessary agreements between responding agencies both within and across jurisdictions.

- Response-Providing support and assistance immediately, limiting the probability of further harm and reducing recovery difficulties.

- Recovery-It is necessary to provide urgent assistance during the critical early recovery phase in order to restore key life support systems to near-normal functioning levels and to continue to assist until the community returns to normal.

\subsection{Crisis management plan}

A crisis happens unexpectedly and can destroy a good business organization's reputation immediately. The COVID-19 crisis, which began in early 2020, is likely to be a case study in crisis management. Worldwide companies have had to close their doors, hundreds of thousands of employees were sent home. Important services will ultimately be judged on their crisis management capabilities. Organizations of all sizes should therefore be serious about crisis management and at least be aware of this issue as crises are seen as one of the greatest threats to business reputation (Šontaitė-Petkevičienè, 2014).

The term "crisis management" means the detection process of threats to an organization and its stakeholders to respond effectively. According to Paxson (1991), crisis management entails assisting in averting crises or handling them more effectively once they occur. Crisis management is also a component of an organizational risk management system that begins ideally with an extensive audit to identify key issues before a crisis occurs. In view of global uncertainty, many modern companies are trying to anticipate future crises in order to 
formulate contingency plans. In the event of a crisis, a dramatic change of direction must be made in the retail sector to ensure survival.

\subsection{Continuity response}

One part of the Business Continuity Plan (BCP) is planning preventive measures against risks and how the response of a company when facing the risks. Continuity response focuses on continuing business operations until things get back to normal. The method aims to protect the company's assets in the event of a catastrophe, including its mission capacity, operating capacity, reputation and image, clients base and market share, and profitability (Hiles, 2015; Supriadi \& Sui Pheng, 2018). This is considered the primary process owing to the critical output it produces for the company in dealing with interruptions and resolving crises. This planning process will be monitored and updated on a regular basis. According to Hiles (2015), a business's risk management strategy should not be driven just by likelihood, but rather by the repercussions and consequences of an unexpected occurrence. Fundamentally, it aims to reduce the effect of a disaster by assuring the availability of alternate mission-critical capabilities in the event of a disaster.

\subsection{Recovery response}

The recovery of firms and others is an important element of economic and community recovery (Stevenson et al., 2018). Recovery is a nebulous notion with a wide range of theoretical and operational applications (Johnson \& Hayashi, 2012). Recovery is described as the process of planning and implementing non-essential business processes and functions once critical business process functions have been restarted and projects/operations that allow the retail organization to return to a standard level of service have been implemented (Supriadi \& Sui Pheng, 2018). In this study, we focus on the biological catastrophe of Covid19, as opposed to natural disasters, where outbreaks like Covid-19 are long-term. A pandemic forces an organization to think outside or beyond the ordinary emergency management cycle (Fakhruddin et al., 2020). The solidity, complexity, and relativism of recovery indicators vary widely, and many of them may be useful based on the research's aim, objective, and scope (Platt et al., 2016). Biological disasters are difficult to recover from and respond to because of their complexity (Fakhruddin et al., 2020). Therefore, businesses need to consider the response that the organization will take to achieve the level of recovery proposed by Alesch et al. (2001). Definition of response according to Purpura (2013) is a short-term, direct-effects action intended at saving lives, protecting property, and meeting fundamental human needs. Therefore, in this study, we define recovery response as the activity of an organization in developing a detailed plan to affect the recovery of critical services of an organization affected by a biological disaster that has a long-term impact.

\subsection{Identification of risk}

Risk identification is an important step in risk management. The identified risks are those that have the potential to prevent the retail business from achieving its goals. The identified risks are categorized into strategic risk, compliance risk, operational risk, financial risk, and reputational risk. There are eight risks identified as risks in retail, following the categorization of the eight risks: 


\subsubsection{Strategic risk of retail}

A strategic risk is a collection of external events and trends that threaten a company's growth and worth. Stalled industries, technologies, brands, rivals, customers, initiatives, and organizations are classified as strategic risks by Slywotzky \& Drzik (2005). There are three identified risks that fall into the strategic risk category of retail, especially the department store sector. The first risk is disruptive technology risk, defined as technology that intentionally replaces conventional technology and affects the way businesses operate. Businesses that fail to account for the effects of disruptive technologies may lose market share to competitors that have discovered methods to integrate those technologies.

Second is digital technology advances, where competitors in department stores are progressively utilizing digital technology as a business procedure in sales and marketing These competitors risk taking market share away from retail in the future, making the department store segment smaller than digital platform firms that are digitizing. Then customer buying behavior, refers to the actions people take before purchasing a product or service, both online and offline. During the COVID-19 pandemic, social and human movements had a significant impact on the lifestyle and buying habits of consumers today and in the future.

\subsubsection{Compliance risk of retail}

Compliance risk is a systematic way of discovering, analyzing, rating, and processing tax compliance risks(e.g., failure to report tax liabilities properly, failure to register, etc.), according to the OECD (2004). The risks that are categorized as compliance risk are regulatory risk. Regulatory risk is the possibility that changes in laws and regulations will have a significant negative impact on security, business, industry, or markets. Changes in government or regulatory agency rules or regulations can increase the cost of doing business, make investments less appealing, or alter the competitive environment. Regulatory risk expresses concern about the regulator's commitment to regulatory measures that encourage non-contractual investments by regulated firms (Fiocco \& Guo, 2020).

\subsubsection{Operational risk of retail}

The risk of loss caused by insufficient or failed internal processes, people, and systems, as well as external events, is referred to as operational risk. The media and public statements made by consumers, employees, and other stakeholders are common sources of reputational risk. Risk that catgeorized as operational risk of retail is human environemntal damge and organisational changes. Human environmental damage, one type of human-environmental risk is the spread of the COVID-19 virus from one person to another, which in the department store consumers are afraid of being exposed to the virus, many workers are laid off to reduce the company's burden, and even following government regulations for shorter operating hours even store closures within a certain period. Then organisational changes that refers when a corporation or organization undergoes a major change in its culture, technology, infrastructure, or internal processes. Resistance, leadership influence, operational disruption, and forced change are some of the risks involved with organizational transformation.

\subsubsection{Financial risk of retail}

Financial risk refers to the danger of losing money in an investment or commercial endeavor. Interest parties can lose money because to the dangers of financial risk. Default on debt is a 
real threat for businesses, as is the failure of a project that places a significant financial strain on the company. The first fianncial risk of retail is commodity price shock, this risk have a direct impact on consumer prices (the first-round effect), but they can also have an indirect impact on the prices of other commodities and services through effects on production costs or firm pricing determination (the second-round effect). If this effect on inflation lasts for a long time (e.g., more than a year), it raises the question of how monetary policy should respond to commodity price shocks (Sekine \& Tsuruga, 2018). Financial crises, the second financial risk of retail, can be precipitated by internal concerns like poor cash flow management or external factors like a sagging economy, natural disasters, or infections like Covid-19, among others. When a financial crisis strikes, all stakeholders in the firm must act quickly to avoid financial consequences.

\section{METHODOLOGY}

Semi-systematic or narrative review techniques were developed for subjects whose concepts differed and were investigated by several research groups in different fields, which prevented a complete systemic assessment procedure (Wong et al., 2013). Semi-systematic reviews generally examine how research has evolved over time in a particular area or how a topic has evolved within a research tradition (Snyder, 2019). Generally, the review seeks to recognize and understand all research traditions which have an impact on the subject studied, using meta-narratives rather than measuring effect sizes (Wong et al., 2013). And in this study, we review the development of research related to business continuity in the retail industry area and focus on grocery and department stores. The choice of method in the study is appropriate because based on Ward et al. (2009), this kind of semi-systematic review analysis can be useful for the detection or identification of components of a theoretical concept, for theoretical perspectives, or general problems within a particular discipline or research process.

According to (Burggräf et al., 2020), there are 4 stages of literature search, namely;

- Identification Phase: Keywords, database, and year range are determined. Keywords, identified in the conceptualization phase, are used in the online database.

- Screening: The second phase includes journaling and keyword filtering. Browse the list of all journals in the database that have been created in Excel. After that, a keyword filter is applied to the title and subtitle.

- Feasibility Assessment: The first step is to evaluate the title and subtitle of each paper one by one. The second step is to read and evaluate the abstract.

- Submitting papers: This step is the process of submitting papers that have the potential to be missed through keyword searches or filtered out due to misleading titles.

ScienceDirect is used as a search database used to view related articles. By entering the keywords "Business Continuity" AND "Business Model" AND "Retail", with the filter article type "research article", 72 articles from the 2004-2022 range were found. Then a table is arranged as a SOTA table 1 for the articles written.

The model used as a reference for the formation of the proposed model in this study was adapted from Griffith University (2021). Griffith University (2021) framework defines a business continuity management technique as well as a risk management continuity planning approach. In addition, a framework for business continuity activities is built utilizing a roadmap. This study, in reference to Griffith University (2021), provides a paradigm that is structured to inform and support sustainable, effective, cross-functional, multi-level sustainability planning through holistic and integrated risk management methods. 
Table 1. SOTA of Business Conitunity Model for Retail Business

\begin{tabular}{|c|c|c|c|c|c|c|}
\hline Title & Year & Authors & $\begin{array}{l}\text { Business } \\
\text { Continuity }\end{array}$ & $\begin{array}{c}\text { Business } \\
\text { Model }\end{array}$ & Retail & Covid-19 \\
\hline $\begin{array}{l}\text { Business continuity of } \\
\text { business models: } \\
\text { Evaluating the resilience } \\
\text { of business models for } \\
\text { contingencies }\end{array}$ & 2019 & $\begin{array}{l}\text { Niemimaa } \\
\text { et al. }\end{array}$ & $\sqrt{ }$ & $\sqrt{ }$ & & \\
\hline $\begin{array}{l}\text { Business continuity in the } \\
\text { COVID-19 emergency: A } \\
\text { framework of actions } \\
\text { undertaken by world- } \\
\text { leading companies }\end{array}$ & 2021 & $\begin{array}{l}\text { Margherita } \\
\text { \& Heikilla }\end{array}$ & $\sqrt{ }$ & $\sqrt{ }$ & & $\sqrt{ }$ \\
\hline $\begin{array}{l}\text { COVID-19 and business } \\
\text { continuity - learning from } \\
\text { the private sector and } \\
\text { humanitarian actors in } \\
\text { Kenya }\end{array}$ & 2021 & $\begin{array}{c}\text { Schmid et } \\
\text { al. }\end{array}$ & $\sqrt{ }$ & & & $\sqrt{ }$ \\
\hline $\begin{array}{l}\text { Business continuity } \\
\text { management in the Arctic } \\
\text { mining industry }\end{array}$ & 2021 & $\begin{array}{l}\text { Taarup- } \\
\text { Esbensen }\end{array}$ & $\sqrt{ }$ & & & \\
\hline $\begin{array}{l}\text { Proposed Model of } \\
\text { Business Retail } \\
\text { Continuity Process } \\
\text { during Pandemic Covid- } \\
19 \text { Based on Risk } \\
\text { identification and } \\
\text { Response }\end{array}$ & 2021 & $\begin{array}{c}\text { Pratiwi et } \\
\text { al. }\end{array}$ & $\sqrt{ }$ & $\sqrt{ }$ & $\sqrt{ }$ & $\sqrt{ }$ \\
\hline
\end{tabular}

\section{ANALYSIS AND DISCUSSION}

During the ongoing COVID-19 pandemic, department store companies are trying to overcome a situation where business conditions must continue due to risks that cause the company to lose revenue. Department stores face problems in assessing unpredictable risks due to the COVID-19 pandemic. They must provide an appropriate response to the risk and what appropriate remedial actions if affected by the effects of these emerging risks. Therefore, we try to explain what business risks occur, as well as responses and actions that must be taken by the company when facing these risks.

One of the tools to anticipate and provide solutions to businesses due to the COVID-19 pandemic is business continuity management (BCM). This study adopts the general framework of Griffith University (2021), which divides BCM into three process dimensions which are then further specified into a framework that can be used for department stores. The first process is plan \& prepare, which consists of risk management, then the second process is the response divided into emergency response and crisis management. Then at the last stage of $\mathrm{BCM}$, a response consists of a continuity response and a recovery response.

\subsubsection{Plan and prepare response}

Business Continuity Planning (BCP) is a sub-function of Business Continuity Management (BCM). The BCM approach involves the integration of the disciplines of emergency 
management and crisis management plan (Griffith University, 2021). BC is a continuous planning and preparation process that identifies hazards and vulnerabilities in department stores, potential disruptions, potential consequences for time-sensitive goals and strategic success, effectiveness of existing controls, and options and strategies to improve performance and efficiency (Griffith University, 2021). Emergency response operations include those carried out during and soon following an emergency to stabilize the post-impact situation (Subramaniam et al., 2010). The purpose of crisis management is to assist companies in avoiding crises or managing them more efficiently once they arise (Paxson, 1991). Emergency management is operational, with a primary emphasis on assisting first responders and facilitating the transition to immediate recovery.

The crisis management plan is more strategically oriented, with high-level officials as the primary actors and an emphasis on long-term impact. As a result, existing hazards will be classed as either an emergency reaction or a crisis management plan based on their duration and impact. The classification is considering the duration and effect of these risks. We consider the response for risks that have short to medium effects for 0-5 years to be classified as an emergency response (Mclennan, 2021). Then, we consider the response for risks that have medium to long effects for 5-10 years to be classified as a crisis management plan (Mclennan, 2021). These responses assess the danger over time of not having access to routine work areas, personnel, equipment, or procedures.

\subsubsection{Human environmental damage risk to emergency response}

One type of human-environmental risk is the spread of the COVID-19 virus from one person to another, which in the department store consumers are afraid of being exposed to the virus, many workers are laid off to reduce the company's burden, and even following government regulations for shorter operating hours even store closures within a certain period. The breakout of the COVID-19 pandemic has forced the closure of numerous firms, resulting in significant trade disruptions across the majority of industrial sectors. Retailers and brands are currently confronted with a variety of pressing challenges, including health and safety, supply chain management, people management, cash flow management, customer demand, sales, and marketing (Donthu \& Gustafsson, 2020).

Human Environmental Damage requires an immediate response because the incident is unexpected and directly impacts the company's operations. Therefore, an emergency response is used as an initial step to overcome the implications of the risk of spreading the COVID-19 virus. The emergency response that the company can apply is in the company's operations, with a reduced response to a minimum of direct interaction between workers to other workers and workers to customers. The response that can be done is a hybrid operational process (Parody et al., 2016). Suppose work is done digitally and adding sales channels by doing it digitally. Therefore, the proposition proposed is as follows:

P1: Emergency response for human environmental damage in the work environment is a hybrid business process.

\subsubsection{Disruptive technology risk to emergency response}

Today disruptive technologies provide solutions and innovations for retail businesses to thrive and compete. Disruptive technology is a technology that intentionally replaces established technology and changes the way companies do business. By definition, disruptive technology also carries risks that need to be considered because it can destroy a business. Businesses that 
fail to account for the effects of disruptive technologies may lose market share to competitors who have found ways to integrate those technologies.

The risk of disruptive technologies arises when retailers are unable to understand, model, invest in and adopt a proactive approach to disruptive technologies. Which invests in creating or adopting disruptive technologies carries significant risks, as products resulting from disruptive technologies can take years for businesses to adopt. So there needs to be an emergency response such as using an executive-level risk committee to discuss the broader risks of disruptive technology. An executive-level risk committee can evaluate technology combined with an impartial source that can accurately assess disruptive technology readiness capabilities and can greatly assist appropriate implementation.

P2: Emergency response of disruptive technology risk is an executive-level risk committee in a business.

\subsubsection{Regulatory risk to emergency response}

Regulatory risk refers to the likelihood that changes in laws and regulations will have a major adverse effect on a security, business, industry, or market. Changes in government or regulatory agency rules or regulations can raise the cost of doing business, reduce the attractiveness of investments, or alter the competitive landscape. Regulatory risk reflects apprehension about the regulator's commitment to regulatory measures that encourage noncontractual investments by regulated companies (Fiocco \& Guo, 2020). Therefore, managing regulatory risk will help retailers demonstrate to other retail businesses, the public, and other stakeholders that the retail business is well run and trustworthy.

In the current state of the Covid-19 pandemic, managing regulatory risk requires a good emergency response for retail business players. One of the responses that can be done is back to the regulatory risk life cycle, by paying attention to the steps of identifying activities and services, then Identifying regulators. To identify various retail activities and service provisions, including trading subsidiaries or Community Interest Companies. After doing so, retailers can then identify for each activity and service whether there is a relevant regulator that sets the rules for that activity or service, as there may be a number of other regulators that apply to the retail business. Also, to reduce the regulatory risk posed by the reduction in mitigation rates, retail needs to be done, such as closing department stores that become unprofitable because people's purchasing power offline has changed due to the Covid-19 pandemic. In addition, online store acquisitions and operations can be carried out.

P3: Emergency response of regulatory risk is regulatory risk life cycle (identifying activities and service, then identifying regulator) and mitigates risk such as closing some offline stores then moving to online.

\subsubsection{Comodity shock risk to emergency response}

Commodity prices are defined as an event that occurs in commodity markets and increases demand commodities (speculative or protective strategies) while decreasing supply; alternatively, they can be defined as an episode that occurs in commodity-producing countries and reduces the stock of resources (commodity-specific industries slowing down, conflicts, extreme weather, and environmental disasters). A commodities price boom has a detrimental effect on global real activity and increases inflation. This is a commodity-specific shock (Arigoni, 2020). Commodity price shocks have a direct influence on consumer prices (the first-round effect), but they may also have an indirect effect on prices of other goods and services via effects on production costs or firm pricing determination (the second-round 
effect). If this effect on inflation persists for an extended period of time (e.g., more than a year), it highlights the issue of how monetary policy should react to commodity price shocks (Sekine \& Tsuruga, 2018).

During the COVID-19 pandemic, essential goods underwent significant changes. This risk causes uncertainty in the price of goods and the risk of stockpiling goods that can be excessive or less and makes the need for an emergency response to overcome these problems. Retail businesses reduce the number of categories of goods that are not currently selling in the market and optimize the types of goods that are currently selling so that it can reduce the burden of warehouse storage and get optimal profit from the sale of several categories of goods.

P4: Emergency Response for Commodity Price Shock Risk is the optimization of several categories of goods that are on the rise in the market.

\subsubsection{Financial crisi risk to crisis management}

The 2008 financial crisis and the COVID-19 outbreak in 2020 were two significant occurrences that had a detrimental effect on global financial markets (Chen \& Yeh, 2021). During a financial crisis, asset prices plummet, businesses and consumers become unable to repay debts, and financial institutions face liquidity shortages. Financial crises are frequently accompanied with panics or bank runs, in which investors sell assets or remove money from savings accounts out of fear that their value would drop if the assets remain in the financial institution. Financial crises can be triggered by internal issues such as bad cash flow management or external factors such as a faltering economy, natural disasters, or diseases such as Covid-19, among others. When a financial crisis hits, all business stakeholders must respond to prevent financial problems.

To reduce the likelihood of a financial disaster, business stakeholders must take five critical steps (Kanya, 2020):

1) Determination of the reasons of the financial crisis; financial difficulties are frequently a symptom of a larger issue.

2) Tighten up and eliminate needless expenses; a corporate cost study should be conducted. Then, organizations may choose where and how to cut expenditures.

3) Adopting a new approach to corporate budgeting; business budgets should be tightened. Allocate funds for actions that contribute to firm profitability, such as postponing growth plans, events, or other costly activities.

4) Modify the sales approach; analyze the sales strategy to determine its success or failure. Businesses can then determine what needs to be improved or altered.

5) Monitor corporate cash flow; tracking cash flow on a consistent basis has never been more critical. This will assist the organization in fully comprehending its revenue and expenses. These measures must be taken to demonstrate a business's management capability; this is an assessment of a business's crisis management capabilities.

P5: Crisis management of the financial crisis risk is to make a scenario strategy as an assessment of financial performance.

\subsubsection{Organizational change risk to crisis management}

Businesses must thrive in an ever-changing commercial and economic environment. Organizational change refers to the process by which a company or organization modifies critical organizational components, such as the underlying culture, technology or 
infrastructure, or internal processes. A major source of risk in any change process is that new systems and processes will fail and wreak havoc on the business. Risks associated with organizational transformation include resistance, leadership influence, operational disruption, and forced change. Thus, a company must have organizational change management as a means to leverage change to achieve a successful resolution. This process usually consists of three phases: preparation, implementation, and follow-up. Organizational change management should begin before crisis management, which involves assisting in preventing crises or responding more effectively once they occur (Paxson, 1991).

There are several things that leaders in the retail business can do to reduce risk and increase the chances of success as an organizational change management activity. First, prepare for organizational change management (Stobierski Team, 2020), which is important for defining, understanding, and gathering support for organizational change. Furthermore, a roadmap can be made that can articulate, measure success, explain how the business environment will be affected, and the possible risks that will be faced. Then it is suggested that commitment and belief are important attributes of a leader. The next thing to do is to minimize the impact, which will vary depending on the size and complexity of the company. Lastly, be wary of forced changes.

P6: Crisis management of organizational change that is needed to well prepare for organizational change management.

\subsubsection{Digital technology advance risk to crisis management}

The usage of technology in retail has exploded in the aftermath of the COVID-19 outbreak. Many department stores have been forced to close physical locations and accelerate their transition to technology-based solutions such as online ordering and fulfillment, click and collect, and robot-assisted operations as a result of the shelter-in-place and lockdown procedures implemented to contain the spread of coronavirus (Shankar et al., 2021). For the advanced technology risk, the majority of department shops in Indonesia employ digital technology in marketing to offset the risk associated with conventional promotion tactics such as offline brochures, posters, pamphlets, and other approaches.

However, due to this pandemic, most of the sales methods carried out by department stores rely heavily on channels through offline stores. Meanwhile, department store competitors are increasingly using digital technology as a business process in sales and marketing. The risk of these competitors is that they will increasingly take the market from retail in the future and make the department store segment smaller than digital platform companies that are digitizing. As a result, the danger associated with developing digital technology is that it will be necessary to quickly alter the sales channel process in the context of Indonesian department shops. One strategy for overcoming these technological advances is to implement an omni-channel system. Rigby (2011) defines omni-channel as 'a combination of a sales experience that combines the advantages of a physical business with an information-rich internet shopping experience.' Omni-channel is a strategy that allows consumers to have a seamless shopping experience or interaction. Customers can shop online with a computer, smartphone, or tablet or visit a physical store for the same shopping experience.

P7: Crisis management for digital technology Advance Risk is to develop a multichannel to an omni-channel strategy. 


\subsubsection{Customer buying behavior risk to crisis management}

As a result of social and human movements during the COVID-19 pandemic, it is causing changes in lifestyles and ways of shopping consumers today and even in the future. Based on research conducted by Kohli et al. (2020) also happens in Indonesia's current condition. Data from Bank Indonesia states that in 2020 there will be a $29.6 \%$ increase in the nominal ecommerce transactions from Rp. 205.5 trillion in 2019 to Rp. 266.3 trillion. Changes in consumer behavior are accustomed to making an effort to shop directly at offline stores. Due to the risk of spreading the virus by interacting with other people, there is a change in behavior in choosing online shopping besides because all activities are now mostly done at home. Because this behavior change will continue during the pandemic and even produce new habits afterward, a response to the crisis of consumer behavior change is needed to deal with the risk of losing market share that continues to change to consumers who prefer to shop online. One way to respond to the risk of changing customer behavior is to reshape customer journeys. Starting from how consumers get information, one of the solutions is the shake-up of media mix: further shift to digital. Second, consumers purchase products by doing basket re-composition, a shake-up in hierarchy needs, polarization format, and brand preference evaluation. Finally, where consumers buy the product, it can be through channel mix reevaluation, replacement of offline channels by at-home alternatives, and new channelselection attributes (Kohli et al., 2020).

P8: Crisis management for changing customer behavior is rethinking consumer decision journeys can re-shape consumer behavior

\subsection{Response to recovery}

The second stage in Business Continuity Management is Response. In this second process, of the eight risks described in the first section, each response has been obtained for existing risks, both emergency response for short to mid duration risk and crisis management for the mid-long duration. This section explains the two responses, the action recovery plans carried out by any retail business. Continuity Response is a retail business action in maintaining previous business functions during the Covid-19 pandemic. Meanwhile, recovery response is retail business action in modifying, adding, and adjusting business functions during the pandemic and the circumstances that continue after that.

\subsubsection{Emergency response to crisis management}

Effective emergency and crisis management necessitate rapid and coordinated decisionmaking (Seba et al., 2019). Effective emergency management and crisis response involve rapid decision-making and coordination. Regardless of how your business is organized, managed, and operated, your emergency management strategy should adhere to a single fundamental principle: clearly define duties. If an emergency occurs, having a simple response plan in place that covers a range of comparable situations will assist guarantee that things go more smoothly. To assist emergency management organizations in optimizing response times, a greater understanding of the factors affecting response times is required (French et al., 2015). Additionally, we must implement company-wide rules that are proportionate to the dangers we may face. There is a need for a crisis management team within the organization that plays a critical role in preventing a crisis from developing (Regester, 1996). Plans for emergency response and crisis management must appropriately reflect a company's crisis management principles and serve as the foundation for a 
comprehensive crisis management program. While emergency response can be defined as a reaction to an issue immediately, crisis management is more deliberate in nature.

P9: Emergency response and crisis management are needed as methods to identify and assess hazards and vulnerabilities that can harm a business sporting events, canceling conferences, and requiring populations to shelter in place

\subsubsection{Human environmental damage to recovery response}

Global disease containment efforts have included the closure of non-essential companies, social isolation, fewer public gatherings, and an indefinite postponement strategy. COVID19 's expansion has prompted governments to take drastic actions, including shutting down significant social and economic sectors, putting global pressure on all sectors, and unexpectedly hurting the economy (Kuckertz et al., 2020). Globally, the COVID-19 contingency has impacted economies and supply systems, costing millions of firms and entrepreneurs (Cañete, 2020). According to Brooks et al. (2020), financial losses associated with unexpectedly ceasing professional activity and loss of social connection are risk factors for the formation of psychiatric disorders and anxiety symptoms. As a result, action is required to assist in mitigating this impact. On the other hand, recent research indicates that strengthening business initiatives has aided countries in resolving conflicts (Portuguez Castro \& Gómez Zermeño, 2020).

The majority of the world's countries have made significant sacrifices in terms of human and economic losses, and some countries are still making sacrifices (Bhattacharya \& Paul, 2020). Times of crisis and recovery afford us the opportunity to examine and research the effects of institutional change on corporate strategy and operations (Sarkis, 2021). For the foreseeable future, this pandemic - which remains undetermined - and its reaction will be a matter of discussion. According to the research reviewed, crises can create chances for businesses to become more resilient, proactive, learn from their mistakes, and engage on social and regional issues (Portuguez Castro \& Gómez Zermeño, 2020).

P10: The recovery response for human environmental damage response is to keep innovating.

\subsubsection{Emergency response of disruptive technology to continuity response}

Disruptive technologies open up new options for users to accomplish things they previously couldn't (Flavin, 2016). According to Christensen, disruptive technology enables new users to engage with technology. He argued that competing with non-consumers is a critical aspect in enabling disruptive innovations to succeed (Christensen et al., 2017). Recent studies of disruptive technologies give light on how incumbent technologies might be displaced or endangered by emerging technologies, as well as on how established enterprises frequently fail to commercialize these new technologies. The company must pursue a targeted and powerful strategy but also generating structure and improvisation, and keep its current competitive advantage while always adapting and creating new ones, especially in this pandemic period.

The external environment's characteristics, such as its dynamism and degree of uncertainty, as well as the dynamic and uncertain regions of corporate organization (DiMaggio \& Powell, 1983), will operate as a buffer against the impact of technology disruption on organizational difficulties. That is, environmental dynamism and uncertainty account for a substantial part of why organizations exhibit various characteristics. Established technologies necessitate ties 
with internal and external constituents, whereas developing disruptive technologies necessitate new relationships both within and outside the organization, as a result of the competing technologies' distinct organizational areas (DiMaggio and Powell, 1983). Rather than reviewing the history of previous disruptions, it is advantageous to apply disruptive technology theory to forecast when and what type of change will occur (Christensen et al., 2005).

P11: The continuity response for an emergency response of disrupting technology is to constantly adapt.

\subsubsection{Emergency response of regulatory risk to recovery response}

Regulation can have a significant impact on an entire industry, much less on individual businesses (Gerrard, 2003). Businesses should be involved at every stage of the regulatory cycle, from monitoring future policy developments to influencing new regulations to developing and implementing compliance programs, and by contacting corporate defense attorneys and leveraging crisis management plans developed by regulatory intervention subjects and experts (Gerrard, 2001). 2003).

Businesses must take a systematic and deliberate approach to regulatory risk management. They must develop and implement customized compliance programs and then continually evaluate them to ensure that risk management and compliance efforts stay one step ahead of regulators (Gerrard, 2003). Solutions should focus on embedding a culture of compliance across line management, not just establishing compliance measures. The effectiveness of regulatory systems and regulatory entities depends on how policymakers answer questions about the design of regulatory entities, including the functions that regulators control, and the broader regulatory system, i.e. the institutional environment in which regulators operate but do not directly control (Jamison et al., 2005). Consequently, regulatory risk should be seen as an opportunity rather than a burden. Transparency is essential to ensure that all evidence provided to decision-makers, whether facts, views, or arguments, is fully shared (Jamison et al., 2005). Along with regulatory uncertainty, department stores face market uncertainty, particularly varying degrees of potential competitive threats.

P12: The recovery response for emergency response of regulatory risk is the transparency of the regulation.

\subsubsection{Emergency response of comodity shock to recovery response}

Shocks to commodity prices exacerbate macroeconomic imbalances, exacerbating the crisis (Aristizabal-Ramirez \& Canavire-Bacarreza, 2016). The primary challenge in developing countries' current economic predicament is their reliance on commodities to accomplish economic growth when their prices change owing to worldwide commodity price volatility (Nuru \& Gereziher, 2020). Thus, the post-crisis world was defined by commodity price volatility associated with the financial system. If commodities prices are connected to the financial system, there will be tangible consequences for global supply and demand chains (Aristizabal-Ramirez \& Canavire-Bacarreza, 2016). Tang \& Xiong (2012) divide commodity price fluctuations into two phases: those that affect commodity prices and those that can have an effect on sustainable development. For example, (Collier \& Goderis, 2011) conclude that a surge in commodity prices has a negative long-run effect on growth but a positive short-term effect. 
International commodity prices are a critical predictor of economic success for small open economies with large levels of commodity exports ((Grimes, 2006; Kose, 2002; Mendoza, 1995). According to Kaldor (1987), an increase in commodity prices (at any level above a certain threshold) causes inflation in industrialized countries for two distinct but related reasons: (1) Because the increase in the price of raw materials is passed through various stages of processing; and (2) because the increase in the price of raw materials is passed through various stages of processing. Market mechanisms, according to conventional economic theory, work to maintain a long-term fit between expansion in primary product availability and industrial growth. However, the efficiency of this mechanism is greatly dependent on experienced traders' willingness to absorb or release shares in reaction to relatively small changes in market prices. This, in turn, is contingent upon traders having high expectations for each commodity's long-term normal price, deviations from which would be regarded transient (Kaldor, 1987).

P13: The recovery response for emergency response of commodity shock is to maximize market mechanism function.

\subsubsection{Financial crisis management to recovery response}

Developing a scenario strategy as an assessment of financial performance is one of the steps in crisis management, namely the risk of a financial crisis. The next action that can be taken by retail business stakeholders in anticipating a possible failure of crisis management is to perform a recovery response. Analysts and policymakers believe that numerous forces contribute to a demand-driven spread in which 'confidence' affects the aggregate economy's desire to spend, rent, and invest (Angeletos et al., 2018). Financial recovery also includes rebuilding consumer and corporate confidence which can lead to a recovery in investment and spending, and a return to routine in financial markets and the banking system. Restoring confidence depends on the ability of retail companies to integrate the policy measures needed to address immediate difficulties with the changes needed to build a long-term sustainable economic, financial and institutional environment. Low confidence also results in a large measured consumption wedge, since the increased urge to save exerts greater pressure on the real risk-free rate than on the marginal utility growth rate as assessed by econometrics (Ilut \& Saijo, 2021). Therefore, modeling confidence in responding to financial crisis conditions to follow up scenario strategies as an assessment of financial performance is important for how policies affect the equilibrium outcome.

P14: Recovery response of financial crisis risk emergency response is modeling confidence in the scenario strategy as an assessment of financial performance.

\subsubsection{Organizational change to continuity response}

A well-planned organizational change management effort is a form of crisis management. Organizational change management aspires to assist businesses in introducing and implementing changes to their operations, products, processes, or systems in a controlled and coordinated manner, while avoiding problems and risks along the way. Organizational change management may help businesses become more resilient, accelerate recovery from key incidents, and assist in developing contingency plans for cases where change does not proceed as anticipated. The next step that can be taken to implement crisis management is using organizational change management by building a framework for communication and continuity response. Using a structured change management approach will help build awareness of change as business elements become more comfortable with the new way of working. Create a structured communication method that supports remote work will enable 
individuals to stay efficient in their positions. This involves best practice techniques to guarantee that people and clients are aware of, effect on, and the new processes and procedures necessary to accomplish their work. Fear of the unknown and uncertainty is a big aspect of people not being able to stay productive, and any ad hoc approach to managing uninvolved or unprepared people will be ineffective. Comprehensively and consistently communicating organizations can assist to soothe anxieties and eventually preserve the continuity of operations.

P15: Continuity response of organizational change management as crisis management, is using framework of communication and recovery.

\subsubsection{Adverse technology response to continuity response}

Omni-channel is the future of department store in Indonesia, which at the present stage is trying to synchronize between online and offline channels in offering the same customer experience. For sizeable retail store companies with many branches in Indonesia but the increasing shortage of visitors who buy goods coming to outlets, it is time for omni-channel in the development and application stages. Online media is not only used as a means of advertising for marketing but is also used as a sales channel and can offer information related to promos, prices, products and provide the same service offers by coming directly to the outlet. How can Multi-Channel be said to have been integrated between each owned channel? One method of measuring this is by assessing whether the customer experience obtained by consumers in various channels is the same. According to Kozlenkova et al. (2015), omnichannel shopping allows an uniform retail interface across all end-user platforms by allowing for the availability of products in a variety of platform formats. "The word refers to the same thing: an omni-channel structure ensures that content is completely accessible, visible, and correct across numerous networks' (Piotrowicz \& Cuthbertson, 2014; Saghiri et al., 2017).

To start implementing the omni-channel system, two important things are needed: online sales channels and an integrated channeling system. Therefore, the retail business does not completely transform to digital channeling, ultimately eliminating offline sales, but continues to run the two channels in an integrated manner. Because after the COVID-19 pandemic, a new normal has been formed, and the risk of infection has reduced, this omni-channel form can later win business competition competencies in the future.

P16: Continuity Response for Adverse Technology Response is to create online channeling and integrated channels.

\subsubsection{Customer buying behavior response to continuity response}

A customer journey can be defined as 'a story of the customer experience in which discrete touch points illustrate how customers interact with a brand, product, or service of interest' (Clark, 2018). Contrary to what the decision-making literature says, interactions are commonly categorized non-linearly. Additionally, it is multimodal and reflects the process's emotional, behavioral, and cognitive responses. The Consumer Decision Journey (CDJ) is a model that explains how customers make purchases. As a result, it is non-linear, with actions overlapping and repeating until the final purchasing choice is made, rather than sequentially. Three things need to be considered in designing customer journeys, customer-centric, Flexible Journeys Based on Need-Points, and Measuring (and Optimizing) Customer Journeys and Experiences (Cornfield, 2021)). Customer-centric (alternatively referred to as client-centric) business strategy is built on placing the customer first and at the center of your business in order to create a great experience and develop long-term partnerships. Customers do not follow scripts while they are focused on Need-Points. They act on instincts, wishes, whims, 
and preferences, frequently seizing opportunities at the spur of the moment. As a result, it is vital that journeys are not pre-aligned with particular touch points based on the desired outcome of the business. Rather than that, the corporation should strive to apprehend the chain of need points that clients traverse in order to arrive at the intended outcome. Management may analyze the efficiency of their customer journeys - and the experiences that result — by utilizing Customer Performance Indicators (CPIs) (Cornfield, 2020). This approach dictates how well a firm performs at each point of contact with a consumer. Based on that continuity response for changing customer behavior during and after pandemic as:

P17: Continuity Response of changing customer behavior is Customer Decision Journey that focuses on customer centric, needs point, and can be measured.

\subsection{Recovery action}

The third stage in business continuity management is recovery action. The previous section mentioned the relationship between emergency response and crisis management to continuity response and recovery response. In this section, we will explain that continuity response can also be switched to recovery response.

\subsubsection{Continuity response to recovery response}

Due to the nature of pandemics, the way organizations approach and implement organizational structure, tools, and technologies, as well as emergency management, recovery, and business continuity plans will constantly evolve (Fakhruddin et al., 2020). A business continuity plan identifies the personnel, resources, and processes required to maintain business operations in the event of disruptions and/or the loss of critical resources (Pingel et al., 2012). By anticipating the loss and providing appropriate backup information, recovery response provides timely and customized replacements for mission-critical information systems (Pingel et al., 2012). By developing a recovery plan and a business continuity plan, you may ensure that your organization's assets remain available in any condition at an acceptable level (Sahebjamnia et al., 2015). Herbane (2010) argued that the advancement of crisis management strategies has compelled firms to engage in particular business continuity operations. Smith \& Adams (2008) argues that continuity and recovery planning should be focused on strengthening resiliency in the aftermath of a disaster. It is vital to assess and incorporate into rules and strategies the varying impacts of response personnel and recovery operations.

In terms of the pandemic situation, while a number of countries have adopted domestic policies that undermine international cooperation in recent years, and some responses to the COVID-19 pandemic have resulted in bilateral spats, the scale and complexity of this crisis necessitate an international recovery that can only be achieved through global cooperation at all levels. Continuity and recovery plans are developed tactically in response to tactical decisions (Sahebjamnia et al., 2015). Managers of the company may wish to evaluate their continuity and recovery plans, as well as their organization's resiliency level, multiple times based on the various strategic and tactical decisions taken during the pre-disaster period (Sahebjamnia et al., 2015). Indeed, continuity and recovery plans can illuminate the relationships between strategic and tactical decisions and the organization's resilience level, which is typically one of the primary concerns of the company's managers (Sahebjamnia et al., 2015).

P18: Continuity response and recovery response are needed to reveal the interactions between strategic and tactical decisions in the company. 


\subsection{Proposed conceptual framework}

The proposed conceptual framework that has been prepared starts with risk identification as a plan \& prepare stage. There are eight specific risks identified in the retail business department store at this stage. Each identified risk is directed to the second stage, namely response, where each risk is managed through emergency response and crisis management. And the last is the third stage, the recovery stage as the last stage of risk management. The stages consist of continuity response and recovery response which are directed based on the term category of the risk.

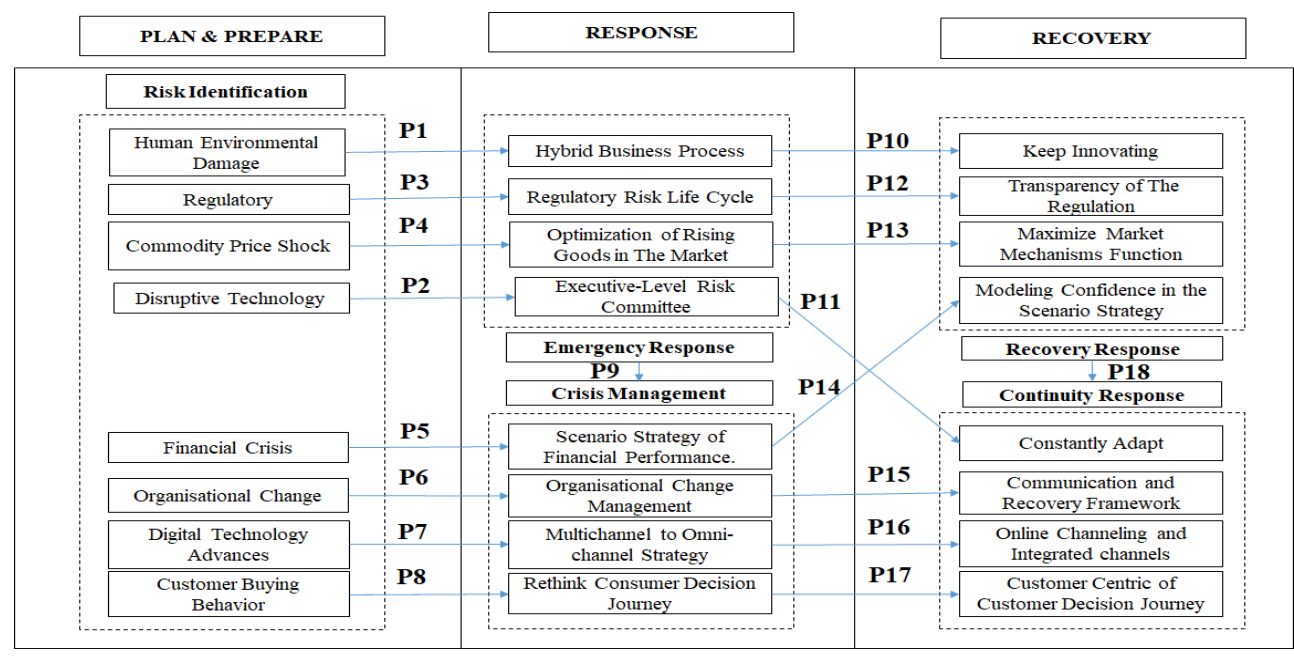

Figure 2. Conceptual Framework of Business Continuity Retail Business during Pandemic Covid-19

\section{CONCLUSION, IMPLICATION, SUGGESTION, AND LIMITATIONS}

From the risk identification that has been carried out, eight risks are obtained which are the plan \& prepare stages. The eight risks are divided into two directions that must be followed at the response stage. Four risks are directed at emergency response, these risks are; human environmental damage, disruptive technology, regulatory, and commodity price shock risk. The four risks are handled through emergency response because these risks are in the form of short to medium-term risks, namely risks caused by the inability of an organization to fulfill and settle its short-term obligations. Then the other four risks, namely; financial crisis, organizational change, digital technology advances, and customer buying behavior, which are geared towards crisis management. Risk is directed at the crisis management stage because it is classified as medium to long-term risks, namely risks caused by the organization's inability to manage scenario analysis and risk strategies.

Each risk that is in the response stage, namely emergency response, and crisis management, is analyzed to be prepared through the recovery stage. The risks that have been directed to be acted upon at the response stage have direct and indirect effects on organizational failure. Responses directed at recovery responses are risks that have a direct impact on the sustainability of the company. And the response directed at the continuity response is a risk that has an indirect impact on the company. Actions that are directed at continuity response, do not all and completely stop there. The response can be directed to a recovery response if it is analyzed that it has the opportunity to experience a failure response on sustainability. 


\subsection{Theoretical implication}

The research was conducted during the Covid-19 Pandemic (Griffith University, 2021), which examined the original structure of business continuity management. This research contributes to the theoretical implications in clarifying the previous business continuity management framework by adjusting the retail business context. The previous framework model describes the business continuity management process in companies and organizations in general. This study tries to provide a clearer picture of the retail business context, especially in department stores. The framework created has also been more specific to the eight risks currently experienced during the Covid-19 pandemic and the situation that will follow. We also clarify the response and recovery action for each of the risks that exist in the framework created.

Additionally, this research contributes to the development of a dependable approach for identifying, analyzing, and mitigating any hazards and threats that may emerge in the future. The paradigm proposed is focused on risk identification, with the implication that if businesses are to survive, let alone prosper, they must take a risk-based approach to strategy execution (Sheehan, 2010). Such a risk-based approach will help companies prepare for unexpected future events, thereby reducing their impact.

\subsection{Managerial implication}

This study provides input to general retail store managers and specific to department stores. The first implication for company managers is that this research can provide a clear picture of how business continuity explains the state of risks that the company is experiencing during the COVID-19 pandemic. How to manage risk appropriately both when risk mitigation is addressed as soon as possible (emergency response) and when the risk is of very long duration (crisis management). This conceptual framework can help company managers make decisions and risk mitigation strategies and quickly adapt to the current conditions of the retail industry.

The second implication of this research also guides department store company managers to switch to digitizing business processes and sales immediately. Because it is an alternative to increase sales during the current pandemic, and even in the future towards omni-channel digital channels are needed to compete in the competition business after this pandemic is over.

The last implication of this research for management is the necessity to establish a business continuity plan to mitigate and prevent existing risks. The purpose of the Business Continuity Plan is to enable businesses to recover quickly from unforeseen disasters such as natural disasters or the current pandemic to continue to function as they should. A business continuity plan should be a high priority for retail business management. Given that managers cannot rule out the chance of a catastrophic catastrophe occurring to their organization, it is critical to have a business continuity strategy in place to address these incidents without jeopardizing the retail business's integrity or mitigating the impact of losses.

\subsection{Limitation and future research}

We realize that this research has some limitations and needs further development for further research. First, this study draws on the results of previous studies using a semi-systematic literature review, and most of the previous research evidence data is not specific to the 
Indonesian context. Therefore, further research can try the business continuity conceptual framework by collecting primary data in the Indonesian context to strengthen the concept that has been made. Second, this research is conceptually strong but lacks in-field data from retail businesses in general or department stores that are needed to strengthen the conceptual framework. Therefore, future research can conduct exploratory research by taking evidence from direct business actors to validate and update the model created. Finally, the research we conducted discussed eight risks and only chose response and recovery, which were discussed in general terms. As a result, the discussion on response and recovery is not in-depth and can provide many alternative responses and recovery. Future research can do specifically to several risks or even specific to one risk. Thus, research can further describe the risks of the existing risks and what alternative responses and recovery are needed to anticipate and overcome the existing risks.

\section{REFERENCES}

Allan, N., \& Beer, L. (2006). Strategic Risk: It's all in your head. University of Bath Schol of Management Working Paper Series, 01.

Angeletos, G.-M., Collard, F., \& Dellas, H. (2018). Quantifying Confidence. Econometrica, 86(5). https://doi.org/10.3982/ecta13079

Aristizabal-Ramirez, M., \& Canavire-Bacarreza, G. (2016). On the Effects of Commodities Prices on Sustainable Development: An Opportunity? Advances in Sustainability and Environmental Justice, 18. https://doi.org/10.1108/S2051-503020160000018005

Bahamid, R. A., \& Doh, S. I. (2017). A review of risk management process in construction projects of developing countries. IOP Conference Series: Materials Science and Engineering, 271(1). https://doi.org/10.1088/1757-899X/271/1/012042

Bhattacharya, S., \& Paul, S. (2020). The behaviour of infection, survival and testing effort variables of SARS-CoV-2: A theoretical modelling based on optimization technique. Results in Physics, 19. https://doi.org/10.1016/j.rinp.2020.103568

Brooks, S. K., Webster, R. K., Smith, L. E., Woodland, L., Wessely, S., Greenberg, N., \& Rubin, G. J. (2020). The psychological impact of quarantine and how to reduce it: rapid review of the evidence. In The Lancet (Vol. 395, Issue 10227). https://doi.org/10.1016/S01406736(20)30460-8

Buganová, K., \& Šimíčková, J. (2019). Risk management in traditional and agile project management. Transportation Research Procedia, 40. https://doi.org/10.1016/j.trpro.2019.07.138

Cañete, N. (2020). Coronavirus: ¿Cómo apoyar desde el sector de fomento a la innovación y las pymes? BID.

Chen, H. C., \& Yeh, C. W. (2021). Global financial crisis and COVID-19: Industrial reactions. Finance Research Letters. https://doi.org/10.1016/j.frl.2021.101940

Christensen, C. M., Anthony, S. D., Roth, E. A., \& Kaufman, R. (2005). Seeing what's next: Using the theories of innovation to predict industry change. Performance Improvement, 44(4). https://doi.org/10.1002/pfi.4140440412

Christensen, C., McDonald, R. M., Altman, E. J., \& Palmer, J. (2017). Disruptive Innovation: Intellectual History and Future Paths. Academy of Management Proceedings, 2017(1). https://doi.org/10.5465/ambpp.2017.14218abstract

Collier, P., \& Goderis, B. (2011). Commodity Prices, Growth, and the Natural Resource Curse: Reconciling a Conundrum. SSRN Electronic Journal. https://doi.org/10.2139/ssrn.1473716

Cornfield, G. (2020). The most important metrics you're not tracking (yet). Harvard Business Review Digital Articles. https://hbr.org/2020/04/the-most-important-metrics-youre-not-tracking-yet

Cornfield, G. (2021). Designing Customer Journeys for the Post-Pandemic World.

DiMaggio, P. J., \& Powell, W. W. (1983). The Iron Cage Revisited: Institutional Isomorphism and Collective Rationality in Organizational Fields. American Sociological Review, 48(2). https://doi.org/10.2307/2095101 
Donthu, N., \& Gustafsson, A. (2020). Effects of COVID-19 on business and research. In Journal of Business Research (Vol. 117). https://doi.org/10.1016/j.jbusres.2020.06.008

Fabeil, F., Pazim, H., \& Langgat, J. (2020). The impact of Covid-19 pandemic crisis on MicroEnterprises. Journal of Economics and Business, 3(2).

Fakhruddin, B. (SHM), Blanchard, K., \& Ragupathy, D. (2020). Are we there yet? The transition from response to recovery for the COVID-19 pandemic. Progress in Disaster Science, 7. https://doi.org/10.1016/j.pdisas.2020.100102

Fiocco, R., \& Guo, D. (2020). Regulatory risk, vertical integration, and upstream investment. European Economic Review, 128. https://doi.org/10.1016/j.euroecorev.2020.103514

Flavin, M. (2016). Disruptive conduct: the impact of disruptive technologies on social relations in higher education. Innovations in Education and Teaching International, 53(1). https://doi.org/10.1080/14703297.2013.866330

French, M. L., Fan, Y., \& Stading, G. L. (2015). An exploratory study of factors influencing emergency response performance. Management Research Review, 38(5). https://doi.org/10.1108/MRR-11-2013-0274

Griffith University. (2021). Business Continuity Management and Resilience Framework. 1-14.

Grimes, A. (2006). A smooth ride: Terms of trade, volatility and GDP growth. Journal of Asian Economics, 17(4). https://doi.org/10.1016/j.asieco.2006.06.005

Herbane, B. (2010). The evolution of business continuity management: A historical review of practices and drivers. In Business History (Vol. 52, Issue 6). https://doi.org/10.1080/ 00076791.2010 .511185

Ilut, C., \& Saijo, H. (2021). Learning, confidence, and business cycles. Journal of Monetary Economics, 117. https://doi.org/10.1016/j.jmoneco.2020.01.010

Kaldor, N. (1987). The role of commodity prices in economic recovery. World Development, 15(5). https://doi.org/10.1016/0305-750X(87)90002-7

Kanya. (2020, April 9). 5 Ways to Overcome a Financial Crisis in Business. https://www.hashmicro.com/blog/overcoming-financial-crisis-in-business/

Kohli, S., Fabius, V., \& Veranen, S. M. (2020). How COVID-19 is changing consumer behavior now and forever. McKinsey \& Company.

Kose, M. A. (2002). Explaining business cycles in small open economies "How much do world prices matter?" Journal of International Economics, 56(2). https://doi.org/10.1016/S00221996(01)00120-9

Kozlenkova, I. V., Hult, G. T. M., Lund, D. J., Mena, J. A., \& Kekec, P. (2015). The Role of Marketing Channels in Supply Chain Management. In Journal of Retailing (Vol. 91, Issue 4). https://doi.org/10.1016/j.jretai.2015.03.003

Kuckertz, A., Brändle, L., Gaudig, A., Hinderer, S., Morales Reyes, C. A., Prochotta, A., Steinbrink, K. M., \& Berger, E. S. C. (2020). Startups in times of crisis - A rapid response to the COVID19 pandemic. Journal of Business Venturing Insights, 13. https://doi.org/10.1016/ j.jbvi.2020.e00169

Mclennan, M. (2021). 16th Edition The Global Risks Report 2021 16th Edition Strategic Partners. In qbusiness.pl.

Mendoza, E. G. (1995). The Terms of Trade, the Real Exchange Rate, and Economic Fluctuations. International Economic Review, 36(1). https://doi.org/10.2307/2527429

Nuru, N. Y., \& Gereziher, H. Y. (2020). The effect of commodity price shock on the Ethiopian economy. Journal of Economic and Administrative Sciences, ahead-of-print(ahead-of-print). https://doi.org/10.1108/jeas-06-2020-0087

OECD. (2004). Compliance Risk Management: Managing and Improving Tax Compliance. In Centre for Tax Policy and Administration.

Pantano, E., Iazzolino, G., \& Migliano, G. (2013). Obsolescence risk in advanced technologies for retailing: A management perspective. Journal of Retailing and Consumer Services, 20(2). https://doi.org/10.1016/j.jretconser.2013.01.002

Parody, L., Gómez-López, M. T., \& Gasca, R. M. (2016). Hybrid business process modeling for the optimization of outcome data. Information and Software Technology, 70. https://doi.org/10.1016/j.infsof.2015.10.007 
Paxson, C. S. (1991). Managing the unthinkable. Dental Economics - Oral Hygiene, 81(1), 29-31, 34. https://doi.org/10.1016/s0090-2616(97)90005-x

Pingel, J., Case, C., Amer, B., Hornung, R. A., \& Schmidt, A. H. (2012). World Marrow Donor Association Crisis Response, Business Continuity, and Disaster Recovery Guidelines. Biology of Blood and Marrow Transplantation, 18(12). https://doi.org/10.1016/j.bbmt.2012.08.006

Piotrowicz, W., \& Cuthbertson, R. (2014). Introduction to the special issue information technology in retail: Toward omnichannel retailing. In International Journal of Electronic Commerce (Vol. 18, Issue 4). https://doi.org/10.2753/JEC1086-4415180400

Portuguez Castro, M., \& Gómez Zermeño, M. G. (2020). Being an entrepreneur post-COVID-19 resilience in times of crisis: a systematic literature review. In Journal of Entrepreneurship in Emerging Economies. https://doi.org/10.1108/JEEE-07-2020-0246

Purpura, P. P. (2013). Resilience, Risk Management, Business Continuity, and Emergency Management. In Security and Loss Prevention. https://doi.org/10.1016/b978-0-12-3878465.00012-7

Regester, M. (1996). Crisis management. Career Development International, 1(5), 26-28. https://doi.org/10.1108/13620439610130614

Saghiri, S., Wilding, R., Mena, C., \& Bourlakis, M. (2017). Toward a three-dimensional framework for omni-channel. Journal of Business Research, 77. https://doi.org/10.1016/j.jbusres. 2017.03.025

Sahebjamnia, N., Torabi, S. A., \& Mansouri, S. A. (2015). Integrated business continuity and disaster recovery planning: Towards organizational resilience. European Journal of Operational Research, 242(1). https://doi.org/10.1016/j.ejor.2014.09.055

Sarkis, J. (2021). Supply chain sustainability: learning from the COVID-19 pandemic. International Journal of Operations and Production Management, 41(1). https://doi.org/10.1108/IJOPM-082020-0568

Scroggins, W. A., Greene, M. R., \& Trieschmann, J. S. (1990). Risk and Insurance. The Journal of Risk and Insurance, 57(2). https://doi.org/10.2307/253314

Seba, A., Nouali-Taboudjemat, N., Badache, N., \& Seba, H. (2019). A review on security challenges of wireless communications in disaster emergency response and crisis management situations. In Journal of Network and Computer Applications (Vol. 126). https://doi.org/10.1016/j.jnca. 2018.11.010

Sekine, A., \& Tsuruga, T. (2018). Effects of commodity price shocks on inflation: A cross-country analysis. Oxford Economic Papers, 70(4). https://doi.org/10.1093/oep/gpy015

Shankar, V., Kalyanam, K., Setia, P., Golmohammadi, A., Tirunillai, S., Douglass, T., Hennessey, J., Bull, J. S., \& Waddoups, R. (2021). How Technology is Changing Retail. Journal of Retailing, 97(1). https://doi.org/10.1016/j.jretai.2020.10.006

Sheehan, N. T. (2010). A risk-based approach to strategy execution. Journal of Business Strategy, 31(5). https://doi.org/10.1108/02756661011076291

Slywotzky, A. J., \& Drzik, J. (2005). Countering the biggest risk of all. Harvard Business Review, 83(4).

Smith, D., \& Adams, J. (2008). Academics or executives? Continuity and change in the roles of provice-chancellors 1. Higher Education Quarterly. https://doi.org/10.1111/j.14682273.2008.00403.x

Subramaniam, C., Ali, H., \& Shamsudin, F. M. (2010). Understanding the antecedents of emergency response: A proposed framework. In Disaster Prevention and Management: An International Journal (Vol. 19, Issue 5). https://doi.org/10.1108/09653561011091904

Tang, K., \& Xiong, W. (2012). Index investment and the financialization of commodities. Financial Analysts Journal, 68(6). https://doi.org/10.2469/faj.v68.n6.5

Tchankova, L. (2002). Risk identification - basic stage in risk management. Environmental Management and Health, 13(3). https://doi.org/10.1108/09566160210431088

Zagorecki, A. T., Johnson, D. E. A., \& Ristvej, J. (2013). Data mining and machine learning in the context of disaster and crisis management. International Journal of Emergency Management, 9(4). https://doi.org/10.1504/IJEM.2013.059879 